\title{
Covalent Immobilization of Lipase in Residual Yerba Mate Stick (Ilex paraguariensis A. St.-Hil.)
}

\author{
Diane Rigo $^{1(\mathrm{D})}$, Paulo Natan Alves dos Santos ${ }^{2,3}$ (D), Bruno Fischer ${ }^{1}{ }^{\text {(D) }}$, Marília Dequi Vendruscolo ${ }^{1(D)}$, \\ Ilizandra Aparecida Fernandes ${ }^{1}$ (D), Alini Tinoco Fricks ${ }^{2,3}$ (D), Rogério Marcos Dallago ${ }^{1}$ (D), \\ Jamile Zeni ${ }^{1, *}$ (D)

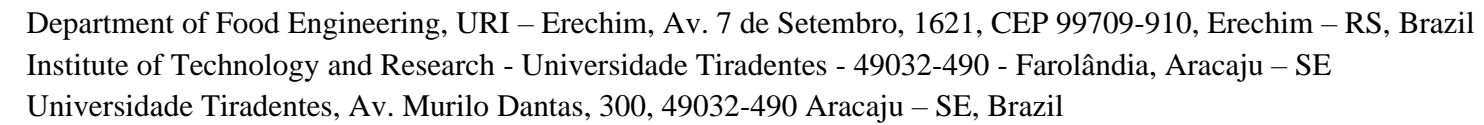

Scopus Author ID 35323468700

Received: 11.02.2021; Revised: 8.03.2021; Accepted: 11.03.2021; Published: 25.03.2021

\begin{abstract}
The objective of this study was to immobilize Eversa ${ }^{\circledR}$ Transform 2.0 lipase on residual yerba mate stick. The stick went through an alkaline pre-treatment and different activation treatments (APTS/glutaraldehyde and sodium metaperiodate). Immobilization was performed using hexane solvent and ammonium nitrate buffer. Support characterization, esterification activity, immobilized enzyme characterization, and operational stability were performed. Characterization by SEM demonstrated that the activation treatments were efficient. The immobilization of lipase on APTS/glutaraldehyde activated support showed a yield of $225.52 \%$ and metaperiodate $162.76 \%$, using hexane as solvent. Good operational stability of the immobilized lipase was observed both in support activated with APTS / glutaraldehyde ( 8 recycles) and in support activated with metaperiodate (5 recycles), maintaining the activity of $65.62 \%$ and $52.00 \%$ in concern to the activity initial, respectively. The optimal reaction temperature was $40{ }^{\circ} \mathrm{C}$ for the free and immobilized enzyme. $\mathrm{K}_{\mathrm{m}}$ and $\mathrm{V}_{\text {máx }}$ values were $16.55 \mu \mathrm{mol} . \mathrm{g}^{-1}$ and $5555.56 \mu \mathrm{mol} . \mathrm{g}^{-1} \cdot \mathrm{min}^{-1}$ for free enzyme; $33.52 \mu \mathrm{mol} . \mathrm{g}^{-1}$ and $4761.9 \mu \mathrm{mol} . \mathrm{g}$ ${ }^{1} \cdot \mathrm{min}^{-1}$ for immobilized enzyme, respectively. The parameters of thermal inactivation confirmed a better thermostability of the lipase in free form.
\end{abstract}

Keywords: alkaline pre-treatment; APTS; glutaraldehyde; organic support; sodium metaperiodate.

(0) 2021 by the authors. This article is an open-access article distributed under the terms and conditions of the Creative Commons Attribution (CC BY) license (https://creativecommons.org/licenses/by/4.0/).

\section{Introduction}

Biocatalysis represents a crucial strategy in sustainable processes, where enzymatic synthesis is typical in several industrial processes. Due to the wide versatility of reactions that catalyze and their specificity in relation to the substrate, lipases (EC 3.1.1.3) are the most used enzymes in biocatalytic processes, being produced by several organisms, such as animals plants, fungi, and bacteria [1-3].

Lipases are enzymes that catalyze a series of reactions such as esterification, hydrolysis of triacylglycerols, transesterifications, and interesterification of oils and lipids. They present essential industrial applications, such as the food industry (for flavor modification), in pharmaceutical products (cosmetics and digestion of fats), elaboration of fine chemicals (synthesis of esters), waste treatment, detergents, among others [4].

Most commercial lipases are single-use and difficult to recover when used in a homogeneous environment, resulting in high operating costs. As an alternative to overcome 
this limitation, enzymatic immobilization stands out. An incorporating enzyme in solid support facilitates recyclability and allowing an increase in activity, specificity, and selectivity of the biocatalyst [5-8].

The enzyme immobilization can generally be carried out by three different methods: covalent bonding on given support, adsorption of enzyme molecules on a support material, and entrapment or encapsulation of the enzyme in polymers [9]. Among these, the methodologies based on the use of covalent bonds stand out, where there is a strong interaction between the enzyme and the support providing immobilized derivatives with greater stability in relation to the leaching of the enzyme from the support [10].

Choosing the immobilization technique and support is an important step. The support must have thermal and microbiological resistance and characteristics compatible with the enzyme to be immobilized [11]. The use of natural supports can be a good alternative, with the use of agro-industrial residues being valid, which present significant economic benefits and reduce disposal problems. Other characteristics of these supports are the large surface area and high porosity that allow the use of high enzymatic loads and the protection of the reaction medium's catalytic site [2].

The yerba mate industry (Ilex paraguariensis A. St.-Hil.) has stuck as an agro-industrial residue. According to the Brazilian Institute of Geography and Statistics (IBGE), Brazil produced around 346 thousand tons of this product in 2016 and many residual sticks, which correspond to approximately $2 \%$ of mass production. These sticks are composed of $34.85 \%$ $\alpha$-cellulose, $24.77 \%$ hemicellulose, $25.78 \%$ lignin, $10.11 \%$ extractives, and $4.49 \%$ ash. These factors emphasize the need for alternative uses for this waste to give it a more dignified destination [12].

Due to the lignocellulosic characteristics of yerba mate that make it resistant to biological and chemical treatments, a pre-treatment capable of destroying lignin and hemicellulose is necessary, allowing better accessibility cellulose. In this case, the use of alkaline pre-treatment has stood out as a favorite for its selectivity in removing lignin and solubilizing carbohydrates, in addition to being able to be carried out in milder conditions than acid pre-treatments [13].

In this context, the present study aimed to evaluate the residual sticks generated from the processing of yerba mate (Ilex paraguariensis A. St.-Hil.) as a support for the immobilization of the Eversa ${ }^{\circledR}$ Transform 2.0 lipase. In response to the process's efficiency, the immobilization yield and the inactivation parameters of the free and immobilized enzyme were evaluated. Although the literature presents a wide variety of studies with enzymatic immobilization on organic supports, no work has been found using the yerba mate stick as a support, making this research innovative.

\section{Materials and Methods}

\subsection{Enzyme.}

Eversa ${ }^{\circledR}$ Transform 2.0 lipase (Novozyme) was donated by an oil company located in the north of the state of Rio Grande do Sul.

\subsection{Yerba mate stick (Ilex paraguariensis A. St.-Hil.).}

The residual yerba mate stick (Ilex paraguariensis A. St.-Hil.) was donated by the herb company Barão Erva Mate e Chás, located in the north of the state of Rio Grande do Sul. 


\subsection{Support functionality.}

\subsubsection{Pre-treatment of the support with $\mathrm{NaOH}$.}

The pre-treatment of the residual yerba mate stick (Ilex paraguariensis) followed the methodology described by Santos et al. [14], with modifications. The process was carried out with $5 \mathrm{~g}$ of the stick holder in a conical flask containing $250 \mathrm{~mL}$ of a $0.5 \mathrm{M} \mathrm{NaOH}$ solution (Vetec). The system was kept under constant agitation $(150 \mathrm{rpm})$ using a magnetic stirrer (Fisatom - Mod. 752A) for $24 \mathrm{~h}$ at room temperature $\left(25^{\circ} \mathrm{C}\right)$. Subsequently, the support was washed with distilled water until neutral $\mathrm{pH}$, filtered, and dried in an oven (Crhomos) at 100 ${ }^{\circ} \mathrm{C}$ until reaching constant mass.

\subsubsection{Silanization and activation of support with APTS/glutaraldehyde.}

The support was silanized according to the methodology described by Queiroz et al. [15], with modifications, using $12 \mathrm{~mL}$ of a solution of $\gamma$-aminopropyltriethoxylan (APTS) (Sigma-Aldrich, $98 \%) 0.5 \%(\mathrm{v} / \mathrm{v})$ in heptane (Sigma-Aldrich) and $1 \mathrm{~g}$ of a residual stick of yerba mate treated with $0.5 \mathrm{M} \mathrm{NaOH}$. The system was kept under constant agitation (40 rpm) at $75^{\circ} \mathrm{C}$ for $3 \mathrm{~h}$. Subsequently, the system was filtered. The support was washed with 3 aliquots $(10 \mathrm{~mL})$ of hexane (P.A. - Química Moderna) to remove excess APTS. The washed stick was kept in an oven (Crhomos) at $100{ }^{\circ} \mathrm{C}$ for $15 \mathrm{~h}$ for complete drying.

Then, the silanized stick was activated with $10 \mathrm{~mL}$ of a $2.5 \%(\mathrm{v} / \mathrm{v})$ aqueous glutaraldehyde solution (Vetec, $25 \%$ ). The mixture was kept for $1 \mathrm{~h}$ at room temperature (25 ${ }^{\circ} \mathrm{C}$ ). Afterward, it was filtered, washed 3 times with $10 \mathrm{~mL}$ of distilled water, and dried in an oven at $100{ }^{\circ} \mathrm{C}$ for $1 \mathrm{~h}$ to remove excess water.

\subsubsection{Activation of support with sodium metaperiodate.}

Activation with sodium metaperiodate followed the methodology described by Coradi et al. [16], with modifications, where $1 \mathrm{~g}$ of the support treated with $0.5 \mathrm{M} \mathrm{NaOH}$ was activated with $10 \mathrm{~mL}$ of $0.1 \mathrm{M}$ sodium metaperiodate. The system remained static, protected from light, for $48 \mathrm{~h}$ to form aldehyde groups. After it was filtered, washed with distilled water 3 times (100 $\mathrm{mL}$ each) and kept in an oven (Crhomos) at $100{ }^{\circ} \mathrm{C}$ for $1 \mathrm{~h}$ to remove moisture.

\subsection{Support characterization-scanning electron microscopy (SEM).}

SEM analyzes were carried out at the Integrated Regional University of Alto Uruguai e das Missões - URI Erechim, using a Zeiss microscope, model EVO LS25. To cover the surface of the sample with gold, a Quorum metallizer, SC 7620 was used. The micrographs were obtained at a voltage of $30 \mathrm{kV}$. The analyzed samples were the following: in natural support; support pretreated with $\mathrm{NaOH}$ and activated with APTS/glutaraldehyde; support pretreated with $\mathrm{NaOH}$ and activated with sodium metaperiodate.

\subsection{Immobilization.}

The immobilization of the lipase in the functionalized yerba mate sticks (APTS/glutaraldehyde or sodium metaperiodate) was performed according to the methodology proposed by Queiroz et al. [15], where $1 \mathrm{~g}$ of the functionalized stick was suspended in $10 \mathrm{~mL}$ of solvent (hexane or ammonium nitrate buffer $\mathrm{pH} 10\left(\mathrm{NH}_{4} \mathrm{NO}_{3}\right)$ ). The systems were kept under mechanical agitation, at room temperature, for $15 \mathrm{~min}$. Then, $0.3 \mathrm{~g}$ of the enzyme was added, 
which corresponds to $30 \%(\mathrm{~m} / \mathrm{m})$ of the support mass, keeping the system under agitation $(100$ $\mathrm{rpm}$ ) for $3 \mathrm{~h}$ at $25{ }^{\circ} \mathrm{C}$ for homogenization, followed by storage in a static condition, at $4{ }^{\circ} \mathrm{C}$, for $24 \mathrm{~h}$.

Subsequently, the support containing the immobilized enzyme was filtered and washed twice with $10 \mathrm{~mL}$ of solvent (hexane or ammonium nitrate buffer) to remove bound nonadsorbed enzymes. After vacuum filtration (MARTE - mod. 131), the immobilized derivative was kept in a desiccator for $24 \mathrm{~h}$ to remove excess moisture and stored in the refrigerator until the time of analysis.

\subsection{Esterification activity.}

The enzymatic activity was evaluated using the esterification method using the methodology described by Hildebrand et al. [17], with modifications, where lauric acid and ethanol were used as a substrate, with a 1:1 molar ratio, free of solvent. According to previous, the reaction was conducted using $0.3 \mathrm{~g}$ of the free enzyme and/or the immobilized derivative at $40{ }^{\circ} \mathrm{C}, 150 \mathrm{rpm}$, for 5 minutes the free enzyme, and 10 minutes the immobilized enzyme tests. Aliquots of $150 \mu \mathrm{L}$ of the reaction medium were diluted in $2 \mathrm{~mL}$ of acetone-ethanol solution $(1: 1 \mathrm{v}: \mathrm{v})$ in a conical flask and analyzed volumetrically using $0.1 \mathrm{M} \mathrm{NaOH}$ with the titrant and phenolphthalein as an indicator.

For white, the procedure was the same but was not added to an enzyme (free or immobilized derivative).

The activity of esterification of the yerba mate stick holder was carried out before the immobilization process to verify that there would be no interference in the activity measure.

A unit of esterification activity ( $\mathrm{U} \cdot \mathrm{g}^{-1}$ of free or immobilized enzyme) was defined as the amount of lauric acid ( $\mu \mathrm{mol})$ consumed per min, per enzyme mass $(\mathrm{g})$, defined by Equation 1 .

$$
E a=\frac{\left(V_{N a O H} \text { white }-V_{N a O H} \text { sample }\right) \cdot 0.1}{t . m} \cdot 1000
$$

Where: Ea: esterification activity $\left(\mathrm{U}^{-1}{ }^{-1}\right)$; $\mathrm{V}_{\mathrm{NaOH}}$ white: Volume of $\mathrm{NaOH}$ spent with the blank test $(\mathrm{mL})$; $\mathrm{V}_{\mathrm{NaOH}}$ sample: $\mathrm{NaOH}$ volume spent after the esterification reaction of each sample (free or immobilized enzyme) (mL); t: Time (minutes); m: Mass of free enzyme or immobilized enzyme used $(\mathrm{g})$.

The immobilization yield $\{\mathrm{Y}(\%)\}$ was calculated according to equation 2 .

$$
Y(\%)=\frac{m_{(I E)} \cdot E a_{(I E)}}{E a_{(F)} \cdot m_{(E)}} \cdot 100
$$

Where: $\mathrm{Y}(\%)=$ Yield obtained from immobilization; $\mathrm{m}_{(\mathrm{IE})}$ is the mass of the immobilized enzyme used for esterification, in $\mathrm{g}$; $\mathrm{Ea}(\mathrm{IE})$ is the esterification activity $\left(\mathrm{U}_{\mathrm{g}} \mathrm{g}^{-1}\right)$ of the immobilized enzyme; $\mathrm{Ea}(\mathrm{F})$ is the esterification activity $\left(\mathrm{U} \mathrm{g}^{-1}\right)$ of the free enzyme; $\mathrm{m}_{(\mathrm{E})}$ is the mass of the free enzyme offered in immobilization, in $\mathrm{g}$.

\subsection{Operational stability (reuse).}

The reuse of the lipase immobilized on a residual yerba mate stick was determined using $0.3 \mathrm{~g}$ of the immobilized derivative, in successive cycles, in batch, for the esterification of lauric acid/ethanol $(1 / 1(\mathrm{~m} / \mathrm{m}))$ at $40{ }^{\circ} \mathrm{C}$ for $10 \mathrm{~min}$. After each batch, the samples were removed from the reaction medium, filtered through a vacuum pump (MARTE - mod. 131), and added to a new lauric acid/ethanol solution. The activity of the first cycle was considered to be $100 \%$. The efficiency of reuse was calculated as presented in Equation 3. 


$$
E R(\%)=\frac{\text { Lipolytic activity }_{\text {cycle } n}}{\text { Lipolytic activity }_{\text {cycle } 1}} .100
$$

Where: ER $(\%)=$ efficiency of reuse; Lipolytic activity cycle $\mathrm{n}=$ lipolytic activity of each cycle; Lipolytic activity cycle $1=$ initial lipolytic activity.

\subsection{Characterization of the immobilized enzyme.}

2.8.1. Reaction temperature evaluation.

To verify the reaction temperature effect, experiments were conducted with the free lipase and the derivative immobilized on the yerba mate stick. As a model reaction, the determination of esterification activity was used at $35,40,45,50,55$ and $60{ }^{\circ} \mathrm{C}$, under the agitation of $150 \mathrm{rpm}$, for $5 \mathrm{~min}$ for the free enzyme and $10 \mathrm{~min}$ for the immobilized enzyme, as previous tests, because above 5 min of reaction the free enzyme starts to lose activity.

2.8.2. Determination of the kinetic parameters constant of affinity $\left(\mathrm{K}_{\mathrm{m}}\right)$ and maximum reaction speed $\left(\mathrm{V}_{\text {máx }}\right)$.

In determining the maximum reaction velocity $\left(\mathrm{V}_{\text {máx }}\right)$ and affinity constant $\left(\mathrm{K}_{\mathrm{m}}\right)$ of the free enzyme and the immobilized derivative, enzyme activity assays were conducted using different ethanol concentrations $(0.668$ to $3.9 \mathrm{M})$ in lauric acid/ethanol substrate. The initial reaction speed $\left(\mathrm{V}_{0}\right)$ was determined for each substrate concentration [S], setting the reaction time variables at $5 \mathrm{~min}$ for the free enzyme and $10 \mathrm{~min}$ for the immobilized enzyme and the temperature maintained at $40{ }^{\circ} \mathrm{C}$. The calculation of the kinetic parameters ( $\mathrm{V}_{\text {máx }}$ and $\mathrm{K}_{\mathrm{m}}$ ) was performed according to the Michaelis-Menten kinetic model, presented in Equation 4 with the Lineweaver-Burk linearization (Equation 5), and the catalytic efficiency was calculated according to Equation 6.

$$
\begin{aligned}
& V_{0}=\frac{V_{\text {máx }} \cdot[S]}{K_{m}+[S]} \\
& \frac{1}{V_{0}}=\frac{K_{m}}{V_{\text {máx }}} \cdot \frac{1}{[S]}+\frac{1}{V_{\text {máx }}}
\end{aligned}
$$

Where: $\mathrm{V}_{0}=$ initial reaction speed; $\mathrm{V}_{\text {máx }}=$ maximum reaction speed; $\mathrm{K}_{\mathrm{m}}=$ Michaelis-Menten kinetic constant; $[\mathrm{S}]=$ substrate concentration.

$$
C E=\frac{V_{\text {máx }}}{K_{m}}
$$

Where: $\mathrm{CE}=$ catalytic efficiency; $\mathrm{V}_{\operatorname{máx}}=$ maximum reaction speed $; \mathrm{K}_{\mathrm{m}}=$ Michaelis-Menten kinetic constant.

\subsubsection{Thermal stability profile.}

Samples of the free enzyme and the immobilized derivative were incubated in closed glass flasks in an oven with controlled temperatures $\left(40,50,60\right.$ and $70{ }^{\circ} \mathrm{C}$ ) for up to $24 \mathrm{~h}$. Periodically, for each temperature, aliquots were removed from each sample and subjected to the activity measure. For each evaluated time, new samples were used, which after the activity dosage were discarded.

Residual activities were calculated as Equation 7.

$$
R(\%)=\frac{U_{F}}{U_{I}} \cdot 100
$$

Where: $\mathrm{R}(\%)=$ is the residual activity; $\mathrm{U}_{\mathrm{I}}=$ initial activity; $\mathrm{UF}_{\mathrm{F}}=$ activity after incubation at the evaluated temperature. 
2.8.4. Estimation of kinetic parameters of inactivation.

The influence of temperature $\left(40,50,60\right.$, and $\left.70{ }^{\circ} \mathrm{C}\right)$ on the enzyme inactivation rate constant $(\mathrm{Kd})$ was analyzed by Arrhenius' law, represented in Equation (8). Ed parameters were calculated by non-linear regression using Excel software.

$$
K d=A e^{\left(\frac{-E d}{R T}\right)}
$$

Where: $\mathrm{Kd}=$ thermal inactivation speed constant; $\mathrm{A} e=$ Arrhenius pre-exponential constant; $\mathrm{Ed}=$ enzymatic deactivation energy; $\mathrm{R}=$ universal gas constant $\left(8.314 \mathrm{x} 10^{-3} \mathrm{~kJ} \cdot \mathrm{mol}^{-1} \cdot \mathrm{K}^{-1}\right) ; \mathrm{T}=$ absolute temperature $(\mathrm{K})$.

The half-life ( $\left.\mathrm{t}_{1 / 2}\right)$ and the decimal reduction value (D), whose values correspond to the times necessary to obtain a 50 and $90 \%$ reduction in the initial activity at a given temperature, were calculated using equations 9 and 10 , respectively.

$$
t_{1 / 2}=\frac{\operatorname{Ln}(2)}{K d}
$$

Where: $\mathrm{t}_{1 / 2}=$ half-life; $\operatorname{Ln}(2)=$ natural logarithm; $\mathrm{Kd}=$ deactivation constant.

$$
D=\frac{\operatorname{Ln}(10)}{K d}
$$

Where: $\mathrm{D}=$ decimal reduction; $\mathrm{Ln}=$ natural logarithm; $\mathrm{Kd}=$ deactivation constant.

The $\mathrm{Z}$ value, specified as the temperature variation required for the $\mathrm{D}$ value to be reduced by a logarithmic cycle, was estimated by the inverse of the line's slope on the log (D) versus temperature $\left({ }^{\circ} \mathrm{C}\right)$ graph.

\subsubsection{Estimation of thermodynamic parameters.}

The thermodynamic parameters enthalpy $\left(\Delta \mathrm{H}^{\mathrm{o}} ; \mathrm{kJ} \cdot \mathrm{mol}^{-1}\right)$, Gibbs free energy $\left(\Delta \mathrm{G}^{\mathrm{o}}\right.$; $\left.\mathrm{kJ} \cdot \mathrm{mol}^{-1}\right)$ and entropy $\left(\Delta \mathrm{S}^{\mathrm{o}} ; \mathrm{kJ} \cdot \mathrm{mol}^{-1} \cdot \mathrm{K}^{-1}\right)$ of the lipase denaturation process, free and immobilized, were determined using equations 11, 12 and 13, respectively:

$$
\begin{aligned}
\Delta H^{\circ} & =E d-R T \\
\Delta G^{\circ} & =-R T \operatorname{Ln} \frac{K_{d} h}{K_{b} h} \\
\Delta S^{\circ} & =\frac{\left(\Delta H-\Delta G^{\circ}\right)}{T}
\end{aligned}
$$

Where: $\mathrm{Ed}=$ enzymatic deactivation energy; $\mathrm{R}=$ universal gas constant $\left(8.314 \times 10^{-3} \mathrm{~kJ} \cdot \mathrm{mol}^{-}\right.$ $\left.{ }^{1} . \mathrm{K}^{-1}\right) ; \mathrm{T}=$ absolute temperature $(\mathrm{K}) ; \mathrm{Kd}=$ denaturation rate constant; $\mathrm{h}=$ is the Plank constant $\left(1.84 \times 10^{-40} \mathrm{~kJ}^{-\mathrm{h}^{-1}}\right) ; \mathrm{Kb}=$ Boltzmann constant $\left(1.38 \times 10^{-26} \mathrm{~kJ} . \mathrm{K}^{-1}\right)$.

\subsection{Statistical analysis.}

All experiments were carried out in duplicate of reaction and titration triplicate; from this, the results obtained through statistical analysis using the Excel software, version 2010, were averaged.

\section{Results and Discussion}

\subsection{Physical characterization of the support.}

When analyzing Figure 1, it can be seen that the fresh stick has a more rigid/smooth structure compared to the activated sticks, which had open grooves in their structures. Of these, the sample activated with sodium metaperiodate $\left(\mathrm{NaIO}_{4}\right)$ showed a greater structural change compared to that activated with APTS/glutaraldehyde. This trend was expected and was linked 
to the different activation mechanisms to which the supports were subjected, more specifically, to the degradative character of the reagents used in each assay. Both supports were pretreated with $\mathrm{NaOH}$, a powerful alkaline agent; however, activation with APTS/glutaraldehyde is less aggressive compared to activation with sodium metaperiodate, a powerful oxidizing agent.

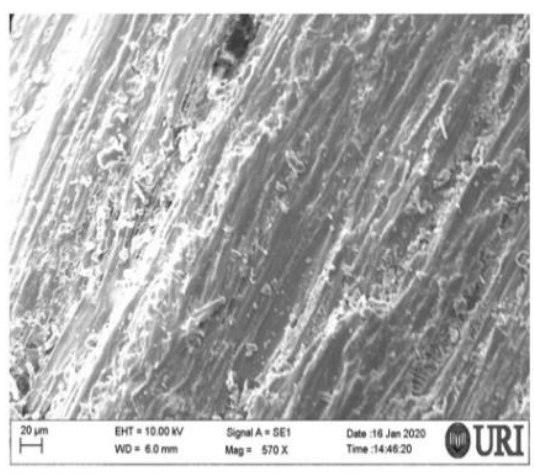

(a)

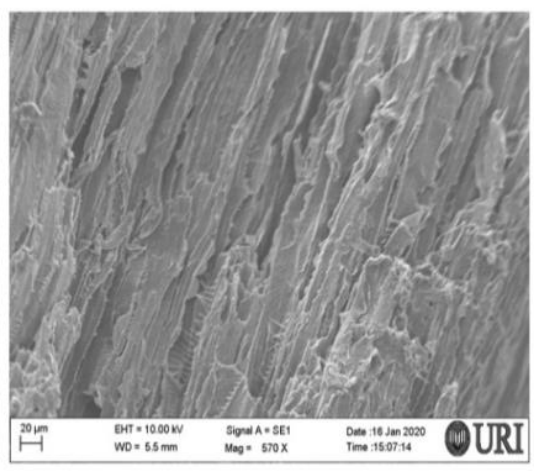

(b)

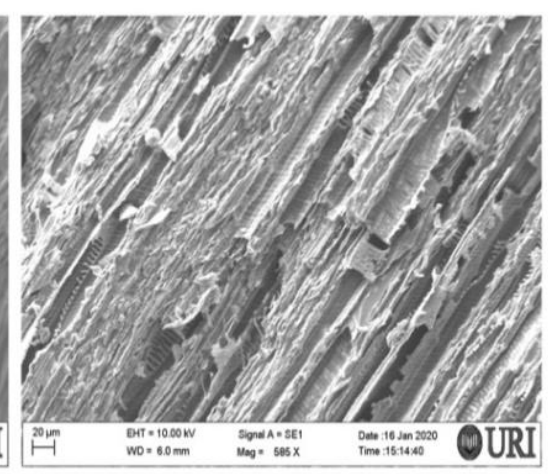

(c)

Figure 1. (a) Visual aspect of the residual yerba mate stick; (b) stick activated with APTS/glutaraldehyde; (c) stick activated with sodium metaperiodate.

\subsection{Immobilization of the Eversa ${ }^{\circledR}$ Transform 2.0 lipase on a residual yerba mate stick.}

The performance results of the Eversa ${ }^{\circledR}$ Transform 2.0 lipase immobilization process on a residual yerba mate, stick activated with different methodologies, considering the use as ammonium nitrate buffer $\mathrm{pH} 10$ and hexane as a solvent, are shown in Table 1.

Table 1. Yield of the Eversa ${ }^{\circledR}$ Transform 2.0 lipase immobilization process.

\begin{tabular}{l|c|c|c|c|c}
\hline Enzyme & Solvent & Total mass $\mathbf{( g )}$ & $\mathbf{U . g}^{\mathbf{- 1}(\mathbf{1})}$ & $\mathbf{U}^{(\mathbf{2})}$ & Yield (\%) \\
\hline Free & & 0.300 & 941.7 & 282.5 & - \\
\hline Immobilized & $\mathrm{NH}_{4} \mathrm{NO}_{3}$ Buffer & 1.485 & 190.6 & 283.1 & 100.2 \\
\cline { 2 - 6 } APTS/Glut. & $\mathrm{Hexane}$ & 1.288 & 494.6 & 637.1 & 225.5 \\
\hline Immobilized & $\mathrm{NH}_{4} \mathrm{NO}_{3}$ Buffer & 1.020 & - & - & - \\
\cline { 2 - 6 } Metaperiodate & Hexane & 1.063 & 432.5 & 459.8 & 162.7 \\
\hline
\end{tabular}

${ }^{(1)} \mathrm{U} \cdot \mathrm{g}^{-1}=$ Enzymatic activity

${ }^{(2)} \mathrm{U}=$ Total activity offered at the derivative

The supports before immobilization did not show any activity for the esterification reaction, demonstrating that they do not interfere in the results obtained with immobilized derivatives.

The free lipase used in the immobilization showed an esterification activity of 941.7

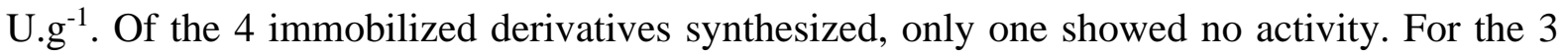
immobilized derivatives that showed activity, the values varied between 283.1 and $637.1 \mathrm{U.g}^{-}$

1. Despite the lower activity values observed for immobilized derivatives, concerning free enzyme, the masses of synthesized immobilized derivatives (between 1.06 and $1.48 \mathrm{~g}$ ), which are at least 3 times higher than that of the free enzyme $(0.3 \mathrm{~g})$, suggest a beneficial effect of the immobilization process, providing immobilization yields (calculated considering the total activities (U) of the free enzyme and derivatives), between 100 and $225 \%$.

Between the two reviews, pre-treatment, regardless of the solvent from the reaction medium, activated with APTS/glutaraldehyde resulted in the generation of immobilized derivatives with higher activity, probably due to more effective generation of reactive sites, more specifically aldehydes end groups for anchoring enzymatic by covalent bonding. 
According to Melo et al. [18], APTS silanization process, using the reaction of its radical with the support silanol group, leading to the formation of an organic bridge with an amine termination, which is subsequently activated with glutaraldehyde, incorporating a necessary aldehyde terminal group for enzyme-support binding, as shown in Figure 2.

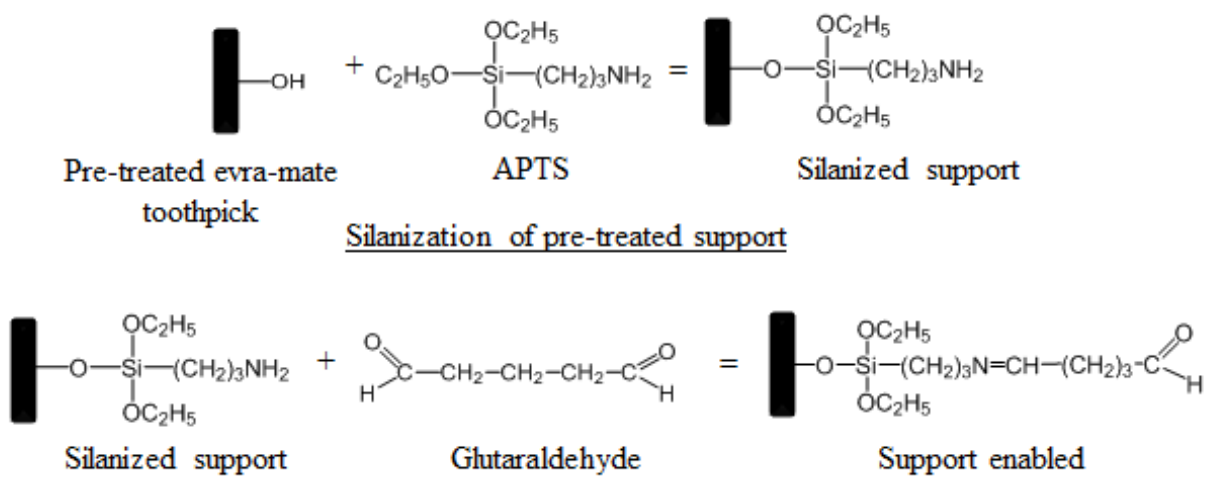

Activation of silanized support with glutaraldehyde

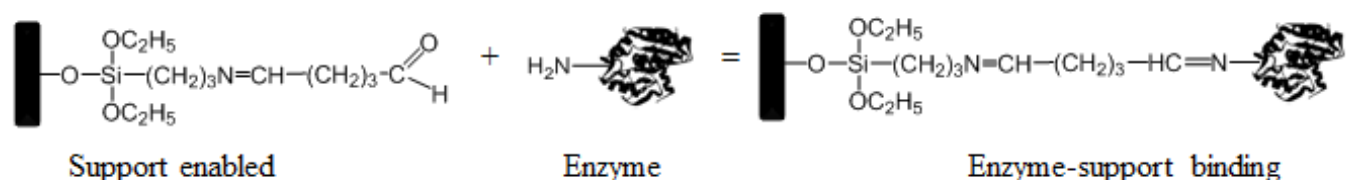

Enzyme immobilization on the silanized and activated support

Figure 2. Signaling and activation process, using APTS/glutaraldehyde, of the residual yerba mate stick for enzymatic immobilization.

In the activation with sodium metaperiodate the suggested mechanism is via chemical oxidation of the hydroxyls exposed in the lignocellulosic material in the alkaline pre-treatment to aldehyde groups. The fact that the hydroxyls are not found in terminal carbons, that is, primary, in cellulose, makes the process of generating reactive aldehyde groups on the surface of the support more complex, the efficiency of the process is directly linked to the generation of terminal hydroxyls, by the rupture of $\mathrm{C}-\mathrm{C}$ bonds in cellulose, for later oxidation to aldehyde groups (Figure 3).
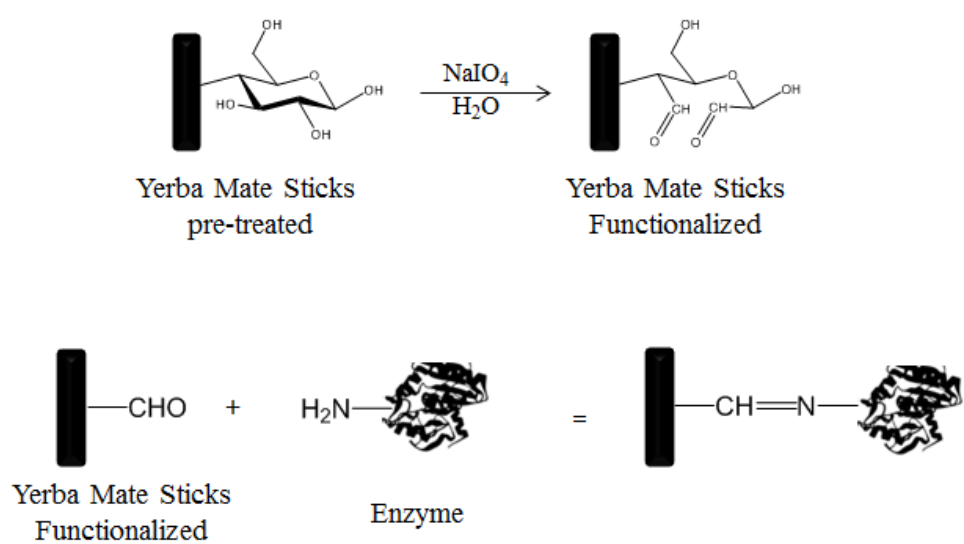

Figure 3. Activation process using sodium metaperiodate on the residual yerba mate stick for enzymatic immobilization.

Another effect observed is related to the reaction medium. The immobilized derivatives synthesized using hexane as a reaction medium, independent of the pre-treatment, activity 
values much higher $(2-3 \mathrm{x})$ than the values observed for the immobilized derivatives synthesized using an aqueous solution of $\mathrm{NH}_{4} \mathrm{NO}_{3}, \mathrm{pH} 10$ as a solvent.

Boudabbous et al. [19] report that in the aqueous medium, the polar groups of proteins are usually located outside the globule in contact with water. However, the enzyme's nonpolar groups are located inside the globule in a protein's hydrophobic nucleus. This can generate biomolecular aggregates with low catalytic activity. These particles can be dissociated by solvents' action, promoting an increase in enzymatic activity due to unimolecular aggregates' formation. The nonpolar solvents have transported nonpolar hydrophobic residues promoting the interface, stabilizing the lipases in their open conformation, and causing these enzymes' hyperactivation [20]. This trend is linked to the maintenance capacity, the hydration layer necessary to maintain the catalytic activity [18]. All of these factors end up resulting in a high conversion rate of the product and viability of the process [21].

In this case, hexane may have caused an effect due to hydrophobic interactions between the solvent and the enzyme, leading to greater catalytic site exposure, which would facilitate catalysis [22]. Another factor is that the nonpolar solvent can break up enzyme aggregates, which normally occur by hydrophobic interaction between protein molecules, improving their dispersion in the reaction medium and supporting enzyme interaction essential for covalently binding. This allows biocatalytic transformations of water-insoluble reagents, opens up new reaction pathways, and can lead to altered selectivities [7].

\subsection{Operational stability (reuse).}

Different trends are observed between the two immobilized derivatives, with the functionalized with APTS/glutaraldehyde presenting a more pronounced loss in the first cycle (Figure 4 (a)), corresponding to $30 \%$, remaining stable, with $\cong 70 \%$ of the residual activity, until the seventh cycle, followed by a further reduction in activity to $50 \%$ of residual activity between the ninth and eleventh cycles. The immobilized derivative activated with metaperiodate presents a less intense loss of activity in the first cycles (with activities of 90 and $84 \%$ for the first and second, respectively). However, this loss of activity is constant, presenting a $50 \%$ loss of activity in the fifth cycle, demonstrating that the immobilization process conducted using the APTS/glutaraldehyde functionalized support leads to the formation of a more stable immobilized derivative.

Duman, Tufan and Kaya [23] explain that recycling the immobilized enzyme can weaken the binding force between the matrix and the immobilized enzyme, which leads to loss of enzyme activity. Also, the active site's conformation can be altered due to the repeated encounter of the substrate with the active site of the immobilized enzyme.

Regarding the 11 cycles with residual activity greater than $50 \%$ observed for the immobilized derivative obtained with functionalized support with APTS/glutaraldehyde, they are superior to those reported by Ding et al. [24], who observed a total of 5 recycles with residual activity of approximately $55 \%$ for the lipase Candida rugosa immobilized covalently in nanoparticles functionalized with APTS. These results are also superior to those found by Ficanha et al. [25], which obtained 6 recycles with residual activity of approximately $51 \%$ using CALB immobilized on air gel modified silica. According to the results, it was decided to use the support activated with APTS/glutaraldehyde and immobilized in a solution containing the hexane solvent to continue the studies concerning the optimal reaction temperature, kinetic parameters $\mathrm{K}_{\mathrm{m}}$ and $\mathrm{V}_{\text {máx }}$, thermodynamic parameters, and thermal inactivation. 


\subsection{Evaluation of the optimal reaction temperature.}

The results regarding the optimal reaction temperature for free and immobilized enzymes (Figure 4 (b)), demonstrated that this lipase, in both situations, can act and have its greatest esterification activity at a temperature of $40{ }^{\circ} \mathrm{C}$, which is consistent with the literature [26-28], which report an optimum range between 40 and $60{ }^{\circ} \mathrm{C}$ for the temperature.

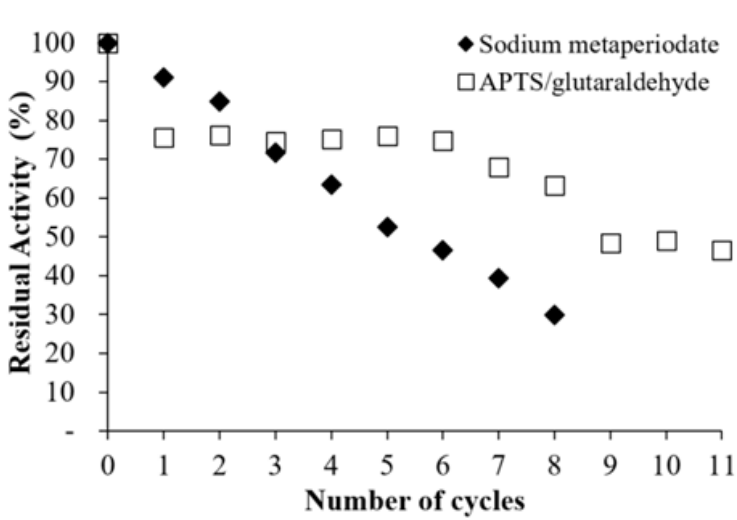

(a)

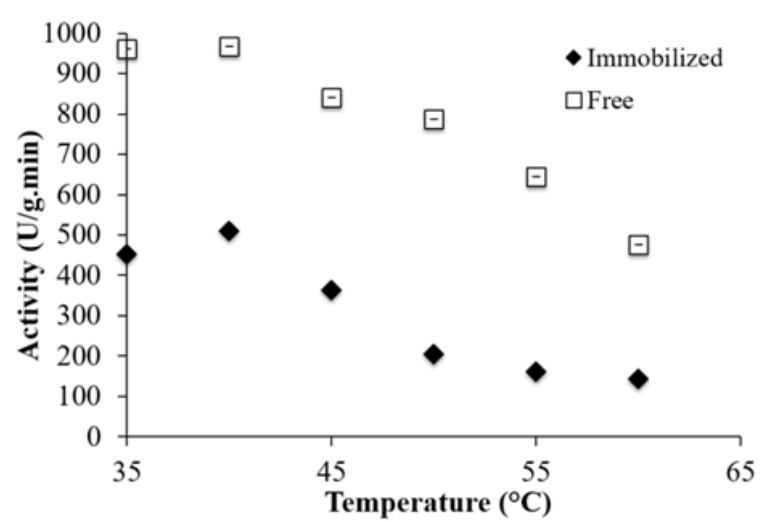

(b)

Figure 4. (a) Capacity/cycles of reuse of the immobilized derivative in the support functionalized with APTS/glutaraldehyde and in the functionalized support with sodium metaperiodate; (b) the effect of the reaction temperature for a free and immobilized enzyme in the support functionalized with APTS/glutaraldehyde.

\subsection{Determination of the kinetic parameters $V_{\text {máx }}$ and $K_{m}$.}

The $K_{m}$ value allows us to dimension the type of interaction between the enzyme and its substrate and varies inversely with affinity; in other words, the smaller the $\mathrm{K}_{\mathrm{m}}$, the greater the affinity. $\mathrm{V}_{\text {máx }}$ is defined as the maximum speed of the total amount of enzyme participating in the reaction. This measure is theoretical and has an approximate value because, at a given moment, it would require that all enzymatic molecules be strongly linked to their substrates [29].

Table 2 presents the values of $\mathrm{K}_{\mathrm{m}}$ and $\mathrm{V}_{\text {máx }}$ obtained in this study and the catalytic efficiency values $\left(V_{\text {máx }} / K_{m}\right)$. Concerning $K_{m}$, the lowest value was observed for the free enzyme $\left(16.55 \mu \mathrm{mol} . \mathrm{g}^{-1}\right)$, compared to immobilized, with $33.52 \mu \mathrm{mol} . \mathrm{g}^{-1}$, suggests a greater affinity of the free enzyme for the substrate, which reflects in the greater reaction speed $\left(\mathrm{V}_{\text {máx }}\right)$, with $5555.56 \mu \mathrm{mol} . \mathrm{g}^{-1} \cdot \mathrm{min}^{-1}$ and better catalytic efficiency $\left(\left(\mathrm{V}_{\text {máx }} / \mathrm{K}_{\mathrm{m}}\right)\right.$, with $335.6 \mathrm{~min}^{-1}$, observed for the free enzyme compared to immobilized, with $4761.90 \mu \mathrm{mol} . \mathrm{g}^{-1} \cdot \mathrm{min}^{-1} \mathrm{e} 142.0$ $\min ^{-1}$, respectively.

Table 2. Constant kinetic parameters of affinity $(\mathrm{Km})$ and maximum reaction speed (Vmax) of the free enzyme and immobilized on the functionalized support with APTS/glutaraldehyde.

\begin{tabular}{l|c|c|c|c|c}
\hline & $\mathbf{K}_{\mathbf{m}}\left(\boldsymbol{\mu} \mathbf{m o l . g ^ { - 1 }}\right)$ & $\mathbf{V}_{\text {máx }}\left(\boldsymbol{\mu} \mathbf{m o l . g ^ { - 1 }} \mathbf{m i n}^{-1}\right)$ & $\mathbf{V}_{\text {máx }} / \mathbf{K}_{\mathbf{m}}\left(\mathbf{m i n}^{-\mathbf{1}}\right)$ & Linear model & $\mathbf{R}^{\mathbf{2}}$ \\
\hline Free enzyme & 16.55 & 5555.56 & 335.6 & $0.00298 \mathrm{x}+0.00018$ & 0.98932 \\
\hline $\begin{array}{l}\text { Immobilized } \\
\text { enzyme }\end{array}$ & 33.52 & 4761.90 & 142.0 & $0.00704 \mathrm{x}+0.00021$ & 0.99291 \\
\hline
\end{tabular}

This trend between enzymes was linked to the system's homogeneity when using the free enzyme, which favors the contact of the enzyme with the substrate with the heterogeneous medium when using the immobilized enzyme.

Possible changes in the three-dimensional conformation of the immobilized enzyme may also be contributing, which may be affecting its active sites, as well as the properties of 
the support, such as its hydrophilic or hydrophobic nature of the presence of fixed charges that affect the mode of action of the enzyme, in addition to the largest enzyme mass in the free system with the immobilized one, which has in its composition approximately $20 \%$ of the equivalent in free enzyme [30].

Similar behaviors are reported in the literature for lipases immobilized on other supports. Wang et al. [31] used Aspergillus oryzae lipase immobilized on amphiphilic montmorillonite (Mt) functionalized with 3-aminopropyltriethoxysilane (APTS) and found $\mathrm{K}_{\mathrm{m}}$ values of $0.357 \mathrm{mM}$ and $3.406 \mathrm{mM}$, and catalytic efficiency $\left(\mathrm{V}_{\text {máx }} / \mathrm{K}_{\mathrm{m}}\right)$ of $178.4 \mathrm{~min}^{-1}$ and 91.7 $\mathrm{min}^{-1}$, for free and immobilized lipases, respectively. Kirtikumar and Badgujar [32], when evaluating lipase immobilized in a biocompatible copolymer of polyvinyl alcohol and chitosan, found $V_{\text {máx }}$ values of $50000 \mu \mathrm{mol} . \mathrm{g}^{-1} \cdot \mathrm{min}^{-1}$ for the free enzyme and $36360 \mu \mathrm{mol} \cdot \mathrm{g}^{-1} \cdot \mathrm{min}^{-1}$ for the immobilized enzyme.

Tomke and Rathod [4] evaluated the $\mathrm{K}_{\mathrm{m}}$ and $\mathrm{V}_{\text {máx }}$ of free and immobilized lipase on activated carbon generated from mixed agro-industrial residues of coconut and peanut shell and obtained values for $K_{m}$ of $0.57 \mathrm{mg} / \mathrm{mL}$ and $0.64 \mathrm{mg} / \mathrm{mL}$ and $V_{\text {máx }}$ of 4.62 and $4.71 \mu \mathrm{mol} . \mathrm{g}^{-}$ ${ }^{1}$ for free and immobilized lipases, respectively. The authors link this behavior to a decrease in the conformational flexibility of the immobilized enzyme structure.

For Cal B lipase immobilized in chitosan, Simões et al. [30] found $V_{\text {máx }}$ values of 12050 mmol.g ${ }^{-1} \cdot \mathrm{min}^{-1}$ and $1409 \mathrm{mmol} \cdot \mathrm{g}^{-1} \cdot \mathrm{min}^{-1}$ and for $\mathrm{K}_{\mathrm{m}}$ of $534 \mathrm{mM}$ and $851 \mathrm{mM}$ for free and immobilized lipases, respectively. According to the authors, this behavior suggests a change in the enzyme's affinity for the substrate due to incorporating the enzyme to support the immobilization process.

\subsection{Estimation of thermodynamic and inactivation parameters.}

Considering that the optimum reaction temperature range obtained experimentally, which is consistent with the literature [27-28], was between 40 and $60^{\circ} \mathrm{C}$, the thermostability tests for free and immobilized enzymes were evaluated between 40 and $70^{\circ} \mathrm{C}$.

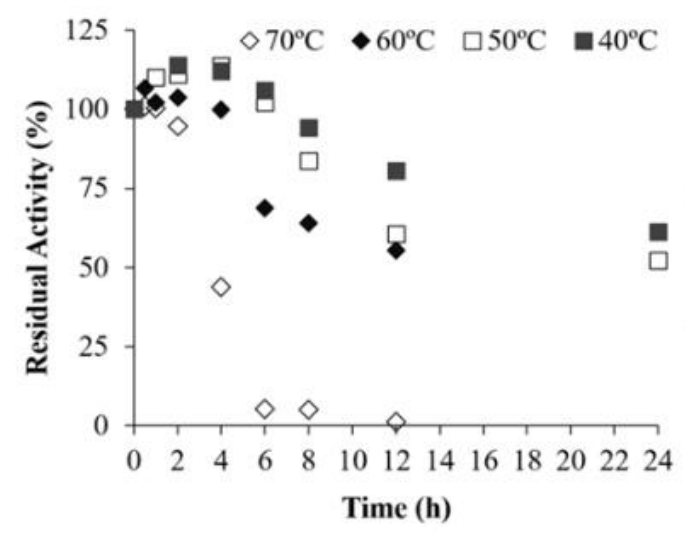

(a)

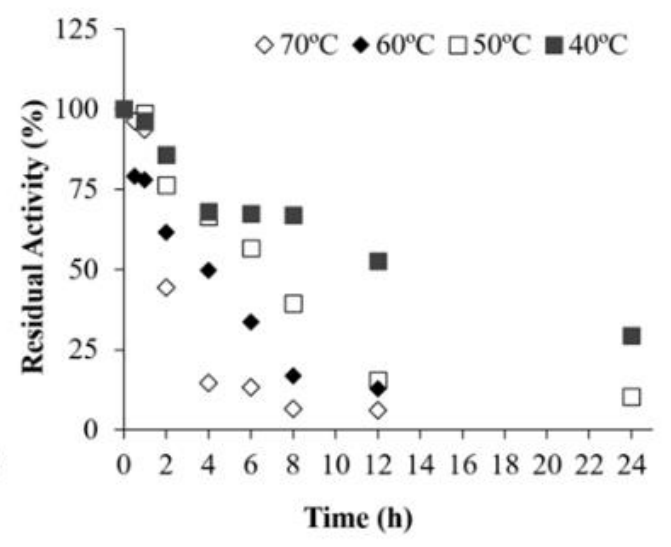

(b)

Figure 5. Thermostability of free lipase (a) and immobilized on the functionalized support with APTS/glutaraldehyde (b) at temperatures of $40,50,60$, and $70^{\circ} \mathrm{C}$.

For both enzymes (free and immobilized), all temperatures evaluated show the same trend, with loss of residual activity as a function of time (Figure 5). This loss of activity varies linearly with temperature, with the tests at 40 and $70{ }^{\circ} \mathrm{C}$ showing the lowest and highest loss of activity, respectively. Among the enzymes, the immobilized activity showed more marked 
losses of activity concerning the free, indicating a negative effect of the immobilization concerning the enzyme's thermostability.

According to Table 3, temperature accelerates the process of thermal inactivation of enzymes, both free and immobilized. The speed at which inactivation of immobilized lipase, represented by the deactivation constant $\left(\mathrm{K}_{\mathrm{d}}\right)$, is greater compared to free lipase, indicating the absence of thermal protection due to immobilization. Comparing the $\mathrm{K}_{\mathrm{d}}$ obtained at temperatures of 40,50 , and $60{ }^{\circ} \mathrm{C}$, it appears that the $\mathrm{K}_{\mathrm{d}}$ of the immobilized lipase was 2.73; 3.69 and 3.48 times greater than those determined for free lipase, respectively.

Chiou $\mathrm{Wu}$ [33], associate the increase in the thermal stability of immobilized enzymes with the fixation in the multipoint support. There was no fixation in the present study's multipoint system, but in a single enzyme-support bonding bridge, reducing thermal stability in concern to the free enzyme.

Another possibility is related to the structural rearrangement and less flexibility of the enzyme in its immobilized form due to the probable lack of multipoint fixations to the support [34].

Table 3. Thermodynamic and thermal inactivation profile of free and immobilized lipase.

\begin{tabular}{|c|c|c|c|c|c|c|c|c|c|c|}
\hline \multicolumn{11}{|c|}{ Free enzyme } \\
\hline $\begin{array}{c}\mathbf{T} \\
\left({ }^{\circ} \mathbf{C}\right)\end{array}$ & $\begin{array}{c}\mathbf{T} \\
(\mathbf{K}) \\
\end{array}$ & $\mathbf{K}_{\mathbf{d}}$ & $\mathbf{R}^{2}$ & $\begin{array}{l}\mathbf{t}^{1} / 2 \\
(\mathbf{h})\end{array}$ & $\begin{array}{c}\text { D } \\
\text { (h) } \\
\end{array}$ & $\begin{array}{c}\mathbf{Z} \\
\left({ }^{\circ} \mathbf{C}\right)\end{array}$ & $\begin{array}{c}\text { Ed } \\
\left(\mathrm{kJJ}^{\prime} \mathrm{mol}^{-1}\right)\end{array}$ & $\begin{array}{c}\Delta G \\
\left(k J . m o l^{-1}\right)\end{array}$ & $\begin{array}{c}\Delta S \\
\left(k J . m o l^{-1}\right)\end{array}$ & $\begin{array}{c}\Delta \mathbf{H} \\
\left(\mathrm{kJ} . \mathrm{mol}^{-1}\right)\end{array}$ \\
\hline 40 & 313.15 & 0.02 & 0.97 & 35.72 & 118.69 & \multirow{4}{*}{48.08} & \multirow{4}{*}{81.26} & 10.03 & 0.097 & -30.36 \\
\hline 50 & 323.15 & 0.03 & 0.99 & 25.96 & 86.23 & & & 9.51 & 0.095 & -30.88 \\
\hline 60 & 333.15 & 0.05 & 0.97 & 13.72 & 45.59 & & & 8.08 & 0.097 & -32.31 \\
\hline 70 & 343.15 & 0.36 & 0.96 & 1.91 & 6.37 & & & 2.83 & 0.109 & -37.56 \\
\hline \multicolumn{11}{|c|}{ Immobilized enzyme } \\
\hline 40 & 313.15 & 0.05 & 0.98 & 13.27 & 44.11 & \multirow{4}{*}{37.03} & \multirow{4}{*}{54.17} & 7.51 & 0.149 & -46.65 \\
\hline 50 & 323.15 & 0.10 & 0.98 & 7.18 & 23.86 & & & 6.14 & 0.148 & -48.03 \\
\hline 60 & 333.15 & 0.17 & 0.98 & 3.97 & 13.21 & & & 4.73 & 0.148 & -49.44 \\
\hline 70 & 343.15 & 0.34 & 0.98 & 2.04 & 6.77 & & & 3.01 & 0.149 & -51.16 \\
\hline
\end{tabular}

The half-life $\left(\mathrm{t}^{1 / 2}\right)$ and the $\mathrm{D}$ value are values that represent the time required for a reduction of $50 \%$ and $90 \%$, respectively. They are important economic parameters in many industrial applications. The higher the values, the greater the thermostability of the enzyme [35]. The free lipase was more stable to thermal inactivation than in the immobilized form, presenting $\mathrm{t}^{1} / 2$ in the range from 35.72 to $1.91 \mathrm{~h}$ and $\mathrm{D}$ values from 118.69 to $6.37 \mathrm{~h}$ (Table 3).

The $\mathrm{Z}$ values were $48.08{ }^{\circ} \mathrm{C}$ and $37.03{ }^{\circ} \mathrm{C}$ for the free and immobilized enzyme, respectively; that is, when the temperature was changed up or down by the $Z$ value, the $D$ value was changed in a logarithmic cycle. The $\mathrm{Z}$ value indicated that large temperature variations are necessary to considerably affect the enzyme's stability, especially concerning it in its free state.

The higher value of deactivation energy $(\mathrm{Ed})$ of the free lipase $\left(81.26 \mathrm{~kJ} . \mathrm{mol}^{-1}\right)$

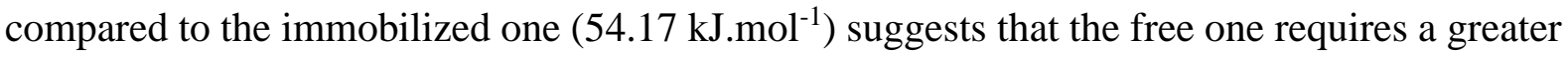
amount of energy to occur the protein unfolding and initiate the process of thermal inactivation, concerning the immobilized enzyme, suggesting that the support was not efficient for the protection of the enzyme against thermal degradation.

Gibbs' free energy measures the spontaneity of the reaction, and protein instability is directly related to $\Delta \mathrm{G}$ values, which, when elevated, indicate greater thermal stability of the enzyme. The positive values of $\Delta \mathrm{G}^{\mathrm{o}}$ for all enzymatic derivatives studied suggest that the lipase's thermal inactivation process is thermodynamically non-spontaneous [36]. In addition, the highest values of $\Delta G^{o}$ recorded for free lipase demonstrated that the state assumed by the 
enzyme, after heat treatment, has greater available energy and the original structural conformation remained more active compared to the immobilized derivative.

The enthalpy $(\Delta \mathrm{H})$ and entropy $(\Delta \mathrm{S})$ parameters provide the number of broken noncovalent bonds and the change in enzyme/solvent disorder associated with the formation of the transition state, where positive $\Delta S$ values suggest that the enzyme split can be a decisive step towards irreversible thermal inactivation of the enzyme. Low $\Delta \mathrm{S}$ values suggest an insignificant disorder in the system and can also be highly influenced by several factors, including the effect of the solvent and structure [37]. In this study, the $\Delta \mathrm{S}$ values were positive for both cases, showing that the reaction is entropically favorable, however, the $\Delta \mathrm{S}$ variation was small. For the immobilized enzyme, the values of $\Delta \mathrm{S}\left(0.148\right.$ to $\left.0.149 \mathrm{~kJ} \cdot \mathrm{mol}^{-1}\right)$, were higher than those observed for the free enzyme $\left(0.095\right.$ to $\left.0.109 \mathrm{~kJ} \mathrm{~mol}^{-1}\right)$, and the temperature was not a factor that influenced this parameter.

Regarding the enthalpy $(\Delta \mathrm{H})$, all values were negative, both for the free enzyme and for the immobilized enzyme, indicating that the thermal inactivation reaction is exothermic, with a greater release of energy into the medium for the immobilized enzyme (-46.65 a -51.16 $\left.\mathrm{kJ} . \mathrm{mol}^{-1}\right)$ concerning free enzyme $\left(-30.36\right.$ to $\left.-37.56 \mathrm{~kJ} . \mathrm{mol}^{-1}\right)$.

Similar results were observed by Antunes [38] for the CALB lipase immobilized in xerogel employing polyvinyl alcohol (PVA) as an additive, presenting higher $\mathrm{K}_{\mathrm{d}}$ values and lower $\mathrm{t}^{1 / 2}$ with the free enzyme, for the evaluated temperature range $\left(40\right.$ to $\left.80{ }^{\circ} \mathrm{C}\right)$. According to the author, the lower thermal stability may be related to the functionality of the support, combined with the temperature, interfering negatively with the enzyme's stability, leading to its loss of activity and, consequently, potentiating the thermal inactivation of the immobilized enzyme with free.

\section{Conclusions}

The proposal to immobilize the Eversa ${ }^{\circledR}$ Transform 2.0 lipase in yerba mate stick residue showed promise for obtaining a derivative immobilized by covalent bonding with good residual activity and an optimum mild reaction temperature. The kinetic parameters observed suggest a better affinity for the substrate from the free enzyme, one of the factors that may justify this is the fact that the immobilized derivative has in its composition approximately 20 $\%$ of the equivalent in a free enzyme. Compared with the free enzyme, the immobilized enzyme did not show such an efficient thermostability, which may be related to the support's functionality, combined with the temperature, interfering negatively with the enzyme's stability.

However, immobilized derivatives showed excellent behavior in relation to reuses, demonstrating that there is the possibility of using supports from agro-industrial residues, which would be discarded in the environment, making it a great alternative to reduce the costs involved in the process of enzyme immobilization.

The results obtained can be a reference base for further research to optimize the process of immobilizing lignocellulosic waste and its subsequent application.

\section{Funding}

This work is funded by the National Council for Scientific and Technological Development (CNPq), Coordination for the Improvement of Higher Education Personnel (Public Notice $\mathrm{n}^{\mathrm{o}}$ : 071/2013 CAPES- PROCAD nº 88881.068489 / 2014-01), and the State Foundation for 
Research Support Rio Grande do Sul (FAPERGS, Process n ${ }^{\circ} 406867$ / 2018-6 and 42750.540.14482.11072019) and the URI.

\section{Acknowledgments}

The authors would like to thank URI Campus Erechim and Universidade Tiradentes for providing the laboratories and materials needed to carry out the work.

\section{Conflicts of Interest}

The authors declare no conflict of interest.

\section{References}

1. Matte, C.R., Bordinhão, C.; Poppe, J.K.; Rodrigues, R.C.; Hertz, P.F.; Ayub, M.A.Z. Synthesis of butyl butyrate in batch and continuous enzymatic reactors using Thermomyces lanuginosus lipase immobilized in Immobead 150. Journal of Molecular Catalysis B: Enzymatic 2016, 127, 67-75, https://doi.org/10.1016/j.molcatb.2016.02.016.

2. Girelli, A.M.; Astolf, M.L.; Scuto, F.R. Agro-industrial wastes as potential carriers for enzyme immobilization: A review. Chemosphere 2020, 244, https://doi.org/10.1016/j.chemosphere.2019.125368.

3. Xie, W.; Xiong, J.; Xiang, G. Enzyme immobilization on functionalized monolithic CNTs-Ni foam composite for highly active and stable biocatalysis in organic solvent. Molecular Catalysis 2020, 483, https://doi.org/10.1016/j.mcat.2019.110714.

4. Tomke, P.D.; Rathod, V.K. A novel step towards immobilization of biocatalyst using agro waste and its application for ester synthesis. International Journal of Biological Macromolecules 2019, 117, 366-376, https://doi.org/10.1016/j.ijbiomac.2018.05.005.

5. Cai, Q.; Huc, C.; Yanga, N.; Wanga, Q.; Wangd, J.; Pana, H.; Hua, Y.; Ruana, C. Enhanced activity and stability of industrial lipases immobilized ontospherelike bacterial cellulose. International Journal of Biological Macromolecules 2018, 109, 1174-1181. https://doi.org/10.1016/j.jbbiomac.2017.11.100.

6. Bilal, M.; Iqbal, H.M.N. Naturally-derived biopolymers: Potential platforms for enzyme immobilization. International Journal of Biological Macromolecules 2019, 130, 462-482, https://doi.org/10.1016/j.ijbiomac.2019.02.152.

7. Ingenbosch, K.N.; Rouseka, A.; Wunschika, D.S.; Hoffmann-Jacobsena, K. A fluorescence-based activity assay for immobilized lipases in non-native media. Analytical Biochemistry 2019, 569, 22-27, https://doi.org/10.1016/j.ab.2019.01.005.

8. Zaitsev, S.Y.; Savina, A.A.; Zaitsev, I.S. Biochemical aspects of lipase immobilization at polysaccharides for biotechnology. Advances in Colloid and Interface Science 2019, 272, https://doi.org/10.1016/j.cis.2019.102016.

9. Savickaite, A.; Sadauskas, M.; Gudiukaite, R. Immobilized GDEst-95, GDEst-lip and GD-95RM lipolytic enzymes for continuous flow hydrolysis and transesterification reactions. International Journal of Biological Macromolecules 2021, 173, 421-434, https://doi.org/10.1016/j.ijbiomac.2021.01.133.

10. Jangi, S.R.H.; Akhond, M.; Dehghani, Z. High throughput covalent immobilization process for improvement of shelflife, operational cycles, relative activity in organic media and enzymatic kinetics of urease and its application for urea removal from water samples. Process Biochemistry 2020, 90, 102-112, https://doi.org/10.1016/j.procbio.2019.11.001.

11. Ficanha, A.M.M.; Antunes, A.; Oro, C.E.D.; Dallago, R.M.; Mignoni, M. Immobilization of Candida antarctica B (CALB) in Silica Aerogel: Morphological Characteristics and Stability. Biointerface Research in Applied Chemistry 2020, 10, 6744-6756, https://doi.org/10.33263/BRIAC106.67446756.

12. Hansen, B.; Borsoi, C.; Júnior, M.A.D.; André Luis Catto, A.L. Thermal and thermo mechanical properties of polypropylene composites using yerba mate residues as reinforcing filler. Industrial Crops \& Products 2019, 140, https://doi.org/10.1016/j.indcrop.2019.111696.

13. Junior, A.D.N.F.; Etchelet, M.I.; Braga, A.F.M.; Clavijo, L.; Loaces, I.; Noya, F.; Etchebehere, C. Alkaline pre-treatment of yerba mate (Ilex paraguariensis) waste for unlocking low-cost cellulosic biofuel. Fuel 2020, 266, https://doi.org/10.1016/j.fuel.2020.117068.

14. Santos, D.T.; Sarrouh, B.F.; Rivaldi, J.D.; Converti, A.; Silva, S.S. Use of sugarcane bagasse as biomaterial for cells immobilization for xylitol production. Journal of Food Engineering 2008, 86, 542-548, http://dx.doi.org/10.1016/j.jfoodeng.2007.11.004.

15. Queiroz, M.L.B.; Conceição, K.C.Da.; Melo, M.N.; Sánchez, O.C.; Alvarez, H.M.; Soares, C.M.F.; Fricks, A.T. Imobilização de peroxidase de raiz forte em bagaço de cana-de-açúcar. Química Nova 2018, 41, 10191024, http://dx.doi.org/10.21577/0100-4042.20170279. 
16. Coradi, M.; Zanetti, M.; Valério, A.; de Oliveira, D.; da Silva, A.; Souza, S.M de A.G.U.; Souza, A.A.U. Production of antimicrobial textiles by cotton fabric functionalization and pectinolytic enzyme immobilization. Materials Chemistry and Physics 2018, 208, 28-34, https://doi.org/10.1016/j.matchemphys.2018.01.019.

17. Hildebrand, C.; Dalla Rosa, C.; Freire, M.G.; Destain, J.; Dariva, C.; De Oliveira, D.; Oliveira, J.V. Fatty acid ethyl esters production using a non-commercial lipase in pressurized propane medium. Ciência e Tecnologia de Alimentos 2009, 29, 603-608, http://dx.doi.org/10.1590/S0101-20612009000300023.

18. Melo, A.F.; Pinto, G.A.S.; Gonçalves, L.R.B.; Ferreira, A.L. De O. Imobilização de Tanase em Suportes Vítreos Utilizando $\gamma$-aminopropiltrietoxilano (ATPS). Comunicado Técnico 2005.

19. Boudabbous, M.; Ameur, R.B.; Belhaj, I.; Cheffi, M.; Belghith, H.; Allouche, N.; Chamkha, M.; Gargouri, A. A novel sec-butyl- $\beta$-D-cellobioside and sec-butyl- $\beta$-D-glucoside biosynthesized by immobilized $\beta$ glucosidase of Fusarium solani with surfactant properties. Applied Catalysis A, General 2020, 602, https://doi.org/10.1016/j.apcata.2020.117713.

20. Quilles, J.C.J.; Brito, R.R.; Borges, J.P.; Aragon, C.C.; Fernandez-Lorente, G.; Bocchini-Martins, D.A.; Gomes, E.; da Silva, R.; Boscolo, M.; Guisan, J.M. Modulation of the activity and selectivity of the immobilized lipases by surfactants and solvents. Biochemical Engineering Journal 2014, 93, 274-280, http://dx.doi.org/10.1016/j.bej.2014.10.009.

21. Cea, M.; González, M.E.; Abarzúa, M.; Navia, R. Enzymatic esterification of oleic acid by Candida rugosa lipase immobilized onto biochar. Journal of Environmental Management 2019, 242, 171-177, https://doi.org/10.1016/j.jenvman.2019.04.013.

22. Aragão, V.C.; Anschau, A.; Porciuncula, B.D.A.; Thiesen, C.; Kalil, S.J.; Carlos Burkert, A.V.; Burkert, J.F.M. Síntese enzimática de butirato de isoamila empregando lipases microbianas comerciais. Química Nova 2009, 32, 2268-2272, http://dx.doi.org/10.1590/S0100-40422009000900005.

23. Duman, Y.A.; Tufan, G.; Kaya, U. Immobilisation of cellulase on vermiculite and the effects on enzymatic kinetics and thermodynamics. Applied Clay Science 2020, 197, https://doi.org/10.1016/j.clay.2020.105792.

24. Ding, C.; Liang, J.; Zhou, Z.; Li, Y.; Peng, W.; Zhang, G.; Zhang, F.; Fan, X. Photothermal enhanced enzymatic activity of lipase covalently immobilized on functionalized Ti3C2TX nanosheets. Chemical Engineering Journal 2019, 378, https://doi.org/10.1016/j.cej.2019.122205.

25. Ficanha, A.M.M.; Antunes, A.; Oro, C.E.D.; Franceshi, E.; Dallago, R.M.; Mignoni, M. Immobilization of Lipase CALB in Organically Modified Silica. Biointerface Research in Applied Chemistry 2021, 11, 78147825, https://doi.org/10.33263/BRIAC111.78147825.

26. Contesini, F.J.; Lopes, D.B.; Macedo, G.A.; Nascimento, M.G.; Carvalho, P.O. Aspergillus sp. lipase: potencial biocatalyst for industrial use. Journal Molecular Catalysis B: Enzymatic 2010, 67, 163-171, https://doi.org/10.1016/j.molcatb.2010.07.021.

27. Jain, R.; Naik, S.N. Adding value to the oil cake as a waste from oilprocessing industry:Production of lipase in solid state fermentation. Biocatalysis and Agricultural Biotechnology 2018, 15, 181-184, https://doi.org/10.1016/j.bcab.2018.06.010.

28. Fraga, F.C.; Valerio, A.; De Oliveira, V.A.; Di Luccio, M.; De Oliveira, D. Effect of magnetic field on the Eversa ${ }^{\circledR}$ Transform 2.0 enzyme: Enzymatic activity and structural conformation. International journal of biological macromolecules 2019, 122, 53-658, https://doi.org/10.1016/j.ijbiomac.2018.10.171.

29. Castro, R.J.; Ohara, A.; Nishide, T.G.; Albernaz, J.R.M.; Soares, M.H.; Sato, H.H. A new approach for proteases production by Aspergillus niger based on the kinetic and thermodynamic parameters of the enzymes obtained. Biocatalysis and Agricultural Biotechnology 2015, 4, 199-207, http://dx.doi.org/10.1016/j.bcab.2014.12.001.

30. Simões, A.S.; Mori, R.Y;, Faria, R.; De Castro, H.F.; Mendes, A.A. Desempenho da matriz híbrida $\mathrm{SiO}_{2-}$ quitosana na imobilização da lipase microbiana de Candida rugosa. Química Nova 2011, 34, 33-38, http://dx.doi.org/10.1590/S0100-40422011000100007.

31. Wang, K.; Sun, S.; Ma, B.; Dong, F.; Huo, T.; Li, X.; Zhao, Y.; Yu, H.; Huang, Y. Construction and characterization of a nanostructured biocatalyst consisting of immobilized lipase on aminopropylfunctionalized montmorillonite. Applied Clay Science, 2019, 183, https://doi.org/10.1016/j.clay.2019.105329.

32. Kirtikumar, C.; Badgujar, B.M.B. Imobilização de lipase em copolímero biocompatível de álcool polivinílico e quitosana para síntese de compostos de laurato em dióxido de carbono supercrítico usando metodologia de superfície de resposta. Process Biochemistry 2015, 50, 1224-1236, http://dx.doi.org/10.1016/j.procbio.2015.04.019.

33. Chiou, S-H.; Wu, W-T. Immobilization of Candida rugosa lipase on chitosan with activation of the hydroxyl groups. Biomaterials 2004, 25, 197-204, http://dx.doi.org/10.1016/S0142-9612(03)00482-4.

34. Torabi, S-F.; Khajeh, K.; Ghasempur, S.; Ghaemi, N.; Siadat, S.-O.R. Covalent attachment of cholesterol oxidase and horseradish peroxidase on perlite through silanization: Activity, stability and co-immobilization. Journal of Biotechnology 2007, 131, 111-120, http://dx.doi.org/10.1016/j.jbiotec.2007.04.015.

35. De Oliveira, R.L.; dos Santos, V.L.V.; da Silva, M.F.; Porto, T.S. Kinetic/thermodynamic study of immobilized $\beta$-fructofuranosidase from Aspergillus tamarii URM4634 in chitosan beads and application on 
invert sugar production in packed bed reactor. Food Research International 2020, 137, https://doi.org/10.1016/j.foodres.2020.109730.

36. Bustamante-Vargas, C.E.; Junges, A.; Venquiaruto, L.D.; Oro, C.E.D.; Julio-Orozco, D.J.; Zabot, G.L.; Tres, M.V.; Paroul, N.; Backes, G.T.; Dallago, R.M. Thermal inactivation kinetics and thermodynamic properties of immobilised Aspergillus niger pectinase in rigid polyurethane foam. International Food Research Journal 2019, 26, 1535-1545.

37. Heidtmann, R.B.; Duarte, S.H.; de Pereira, L.P.; Braga, A.R.C. Caracterização cinética e termodinâmica de $\beta$-galactosidase de Kluyveromyces marxianus CCT 7082 fracionada com sulfato de amônio. Brazilian Journal Food Technology, 2012, 15, 41-49, http://dx.doi.org/10.1590/S1981-67232012000100005.

38. Antunes, A. Imobilização de lipase de Candida antarctica B in situ em matriz hidrofóbica de xerogel e sonogel usando tmos como precursor da sílica com diferentes aditivos. Tese. Programa de Pós-Graduação em Engenharia de Alimentos - Universidade Regional Integrada do Alto Uruguai e das Missões - Campus de Erechim, Erechim/RS, 2019. 